\title{
Methylmercury, total mercury and total selenium in four common freshwater fish species from Ya-Er Lake, China
}

\author{
Lina Jin $^{1}$, Lina Liang ${ }^{2}$, Guibin Jiang $^{2}$ \& Ying $\mathrm{Xu}^{1, *}$ \\ ${ }^{1}$ State Key Laboratory of Freshwater Ecology and Biotechnology, Institute of Hydrobiology, Chinese \\ Academy of Sciences, 430072, Wuhan, China \\ ${ }^{2}$ Key Laboratory of Environmental Chemistry and Ecotoxicology, Research Center for Eco-Environmental \\ Sciences, Chinese Academy of Sciences, 100085, Beijing, China \\ ${ }^{3}$ Author for correspondence (tel.: +86-27-68780607; fax: +86-27-68780607; e-mail: xuying@ihb.ac.cn)
}

Received 7 April 2005; Accepted 6 December 2005

Key words: fish, methylmercury, public health, total mercury, total selenium

\begin{abstract}
Snakehead fish (Ophiocephalus argus cantor), silver carp (Hypophthalmichthys molitrtix), crucian carp (Carassius carassius), and common carp (Cyprinus carpio) are four common freshwater fish species in China. In this study, the level of methylmercury (MeHg), total mercury ( $\mathrm{T}-\mathrm{Hg})$, and total selenium (T-Se) in muscle samples of these four fish species from Ya-Er Lake, China, were analyzed using atomic fluorescence spectrometry coupled with high-performance liquid chromatography, and inductively coupled plasma mass spectrometry. The concentrations of $\mathrm{MeHg}$ in all the fish species were significantly correlated with those of $\mathrm{T}-\mathrm{Hg}$. Higher $\mathrm{T}-\mathrm{Hg}$ and $\mathrm{MeHg}$ concentrations had accumulated in the snakehead fish, which is a strongly predatory fish, than in the other three species. The concentration ratios of $\mathrm{MeHg}$ and $\mathrm{T}-\mathrm{Hg}$ in the muscles of these four fish species were almost equal. Conversely, there was negative correlation between the concentrations of $\mathrm{T}-\mathrm{Hg}$ and $\mathrm{T}-\mathrm{Se}$, which implies that there is a competition between these two elements with respect to bioaccumulation. It is noteworthy that of all the muscle samples tested, the level of $\mathrm{T}-\mathrm{Hg}$ exceeded the maximum allowable limit in fish $\left[0.4 \mathrm{mg} \mathrm{kg}^{-1}(\mathrm{w} / \mathrm{w})\right.$ recommended by the World Health Organization] in $38.46 \%$ of those of the silver carp, $18.18 \%$ of those of the crucian carp, and $100 \%$ of those of snakehead fish. These results show that the consumption of contaminated fish is a potential threat to human health and that necessary preventive measures to safeguard public health should be emphasized.
\end{abstract}

\section{Introduction}

Natural and anthropogenic sources of mercury as well as increasing levels of mercury found in the food chain have resulted in mercury pollution becoming a global problem. Minamata disease, which appeared among inhabitants of Minamata Bay, Japan, was caused by the consumption of fish and shellfish containing high concentrations of MeHg (Tsubaki \& Irukayama 1977), and in Iraq 459 people died following their consumption of Hg-contaminated bread (Bakir et al. 1973). Mercury pollution has also been reported in
Quebec, Canada (Eyssen \& Ruedy 1983), the Amazon in Brazil (Nriagu et al. 1992), and many other areas of the world (Michael 2003).

In water bodies, inorganic mercury $(\mathrm{I}-\mathrm{Hg})$ can be converted into highly toxic organomercury compounds by microbial action. Methylmercury $(\mathrm{MeHg})$, the most toxic species of the organomercury compounds, usually represents more than $85 \%$ of the total mercury ( $\mathrm{T}-\mathrm{Hg}$ ) presenting in fish (May et al. 1987; Bloom 1992), and most of the mercury presenting in humans originates from the consumption of fish. As a result, many national agencies have issued fish guidelines on safe levels 
of exposure to mercury. The U.S. Food and Drug Administration (FDA) has set an action level of $1 \mu \mathrm{g} \mathrm{g}^{-1}(\mathrm{w} / \mathrm{w})$ for concentration of $\mathrm{MeHg}$ in fish. Canada and several U.S. states have even set an advisory consumption level of $0.5 \mu \mathrm{g} \mathrm{g}^{-1}$ (w/w) for $\mathrm{MeHg}$ in fish (EPA 2001). However, mercury levels above the regulatory limits have been observed many times, particularly in species occupying high trophic levels (Monteiro \& Lopes 1990; Nakagawa et al. 1997; Storelli \& Marcotrigiano 2001; Storelli et al. 2002).

Until recently, in China relatively little attention has been devoted to examining the levels of mercury in freshwater fish, despite the economic and culinary important position of these fish in Chinese diets. Ya-Er Lake is located in the eastern part of Wuhan, Hubei province, China. It is a shallow, eutrophic lake along the middle-lower reaches of the Yangtze River (Figure 1) which has been heavily polluted by mercury as a result of the operations of a huge chlor-alkali industrial plant nearby which involves the use of mercury cells (Figure 2). The objectives of the present study were to obtain data on the $\mathrm{T}-\mathrm{Hg}$ and $\mathrm{MeHg}$ concentrations in the muscles of four commonly consumed freshwater fishes obtained from Ya-Er Lake, to determine the T-Se concentration and the possible correlation of $\mathrm{T}-\mathrm{Se}$ with $\mathrm{T}-\mathrm{Hg}$ due to its detoxifying effect, and finally to evaluate the hazard of mercury-contaminated fish consumption to public health.

\section{Materials and methods}

\section{Apparatus}

The $\mathrm{T}-\mathrm{Hg}$ concentrations were measured by atomic fluorescence spectrometry (AFS) (model AF-610A; Raleigh Analytical Instruments, Beijing) using a $253.7 \mathrm{~nm}$ line source with a specially made hollow cathode lamp (Tian-gong Analytical Instrument Factory, Beijing) operating at $280 \mathrm{~V}$ of PMT voltages and $40 \mathrm{~mA}$ of the lamps' current.

The high-pressure liquid chromatography (HPLC) (model LC-10AT; Shimadzu, Japan) and AFS hyphenation system have been described previously (Liang et al. 2003). A ZORBAX ODS

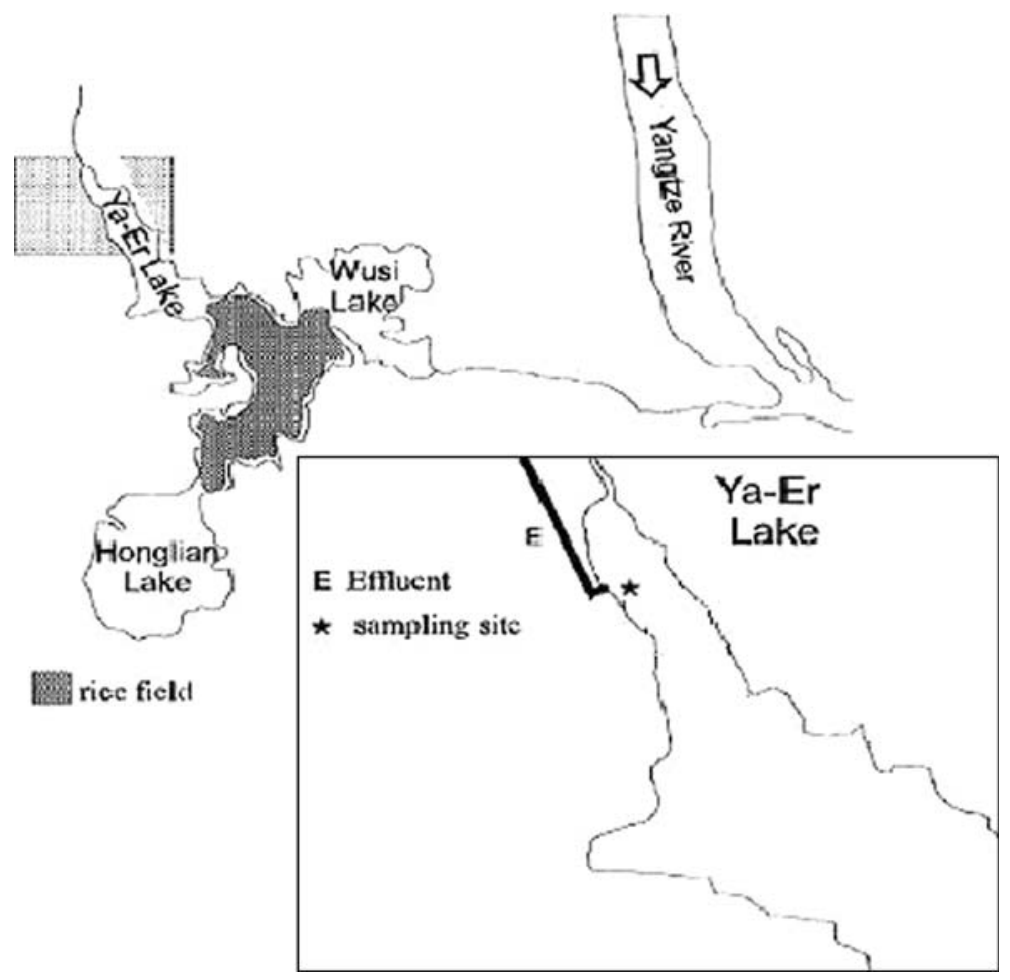

Fig. 1. Map showing Ya-Er Lake and the sampling site. 


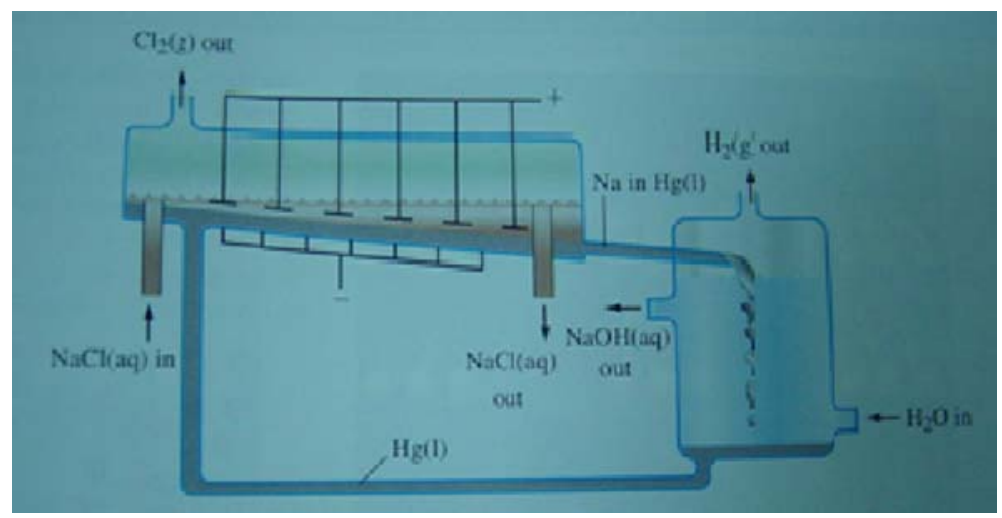

Fig. 2. The old mercury-cell production technique in chlor-alkali industry. The cathode is a layer of Hg (I) that flows along the bottom of the tank. Anodes, at which chlorine gas is found, are situated in the sodium chloride solution just above the Hg (I). Sodium formed at the cathode dissolves in the $\mathrm{Hg}$ (I), and the sodium amalgam is decomposed with water to produce $\mathrm{NaOH}$ (aq) and $\mathrm{Hg}(\mathrm{g})$. The regenerated $\mathrm{Hg}(\mathrm{I})$ is recycled.

column $(4.6 \times 150 \mathrm{~mm}, 5 \mu \mathrm{m}$; Agilent Technologies, USA) was utilized to separate $\mathrm{MeHg}$ in the samples.

Inductively coupled plasma-mass spectrometry (ICP-MS) (model 7500i; Agilent Technologies) was used for the determination of T-Se. The working parameters were: RF power, $1300 \mathrm{~W}$; sampling depth, $7 \mathrm{~mm}$; carrier gas flow rate, $1.051 \mathrm{~min}^{-1}$; makeup gas flow rate, $0.11 \mathrm{~min}^{-1}$; spray chamber temperature, $2{ }^{\circ} \mathrm{C}$; sample uptake rate, $0.4 \mathrm{ml} \mathrm{min}$. The orifice of the nickel sampling cone and skimmer cone was 1.0 and $0.4 \mathrm{~mm}$, respectively.

\section{Sampling sites and dissection of fish}

Fish samples were obtained in November 2002. Four of the most commonly consumed freshwater fish species in Ya-Er Lake were captured in the same day with netting: silver carp (body weight, $0.84 \pm 0.25 \mathrm{~kg} ; n=13$ ), crucian carp (body weight, $0.29 \pm 0.08 \mathrm{~kg} ; n=11$ ), common carp (body weight, $0.33 \pm 0.16 \mathrm{~kg} ; n=10$ ), and snakehead fish (body weight, $0.77 \pm 0.40 \mathrm{~kg} ; n=6$ ). Muscle samples were removed from the fish using stainless steel instruments and stored in plastic bags in accordance with FAO methods (FAO 1983). All of the stainless steel materials were washed with $\mathrm{HNO}_{3}$ and rinsed with deionized water in order to avoid metal contamination from the background. The samples were frozen in liquid nitrogen and further storage at $-80{ }^{\circ} \mathrm{C}$ until analysis.

\section{Analytical methods}

For $\mathrm{T}-\mathrm{Hg}$ and $\mathrm{T}-\mathrm{Se}$ analysis, approximately $0.49-0.51 \mathrm{~g}$ of muscle sample was weighed in a Teflon tube and then digested using $1.0 \mathrm{ml} \mathrm{HNO}_{3}$ by heating the closed tube in an aluminum block and maintaining the temperature at $40{ }^{\circ} \mathrm{C}$ overnight. After cooling, the tube was transferred to an oven and heated first at $50{ }^{\circ} \mathrm{C}$ for $1 \mathrm{~h}$ followed by $4 \mathrm{~h}$ at $160{ }^{\circ} \mathrm{C}$. The solutions were then diluted to $24 \mathrm{ml}$ with Milli-Q water for the AFS determinations. $\mathrm{MeHg}$ was determined following the method described by Liang et al. (2003). Briefly, $3 \mathrm{ml} \mathrm{25 \%}$ $(\mathrm{m} / \mathrm{v}) \mathrm{KOH}$ (in methanol) was added to $0.5 \mathrm{~g}$ wellproportioned wet samples in a $50-\mathrm{m}$ centrifuge tube and shaken mechanically overnight. Then $3 \mathrm{ml}$ of $6 \mathrm{~mol} \mathrm{l}^{-1} \mathrm{HCl}, 4 \mathrm{ml}$ acidic $\mathrm{KBr} / \mathrm{CuSO}_{4}$ (3:1), and $5 \mathrm{ml} \mathrm{CH}_{2} \mathrm{Cl}_{2}$ were added into the tube in sequence, followed by $2 \mathrm{~h}$ of shaking to extract the organic mercury into the $\mathrm{CH}_{2} \mathrm{Cl}_{2}$ phase. Following centrifugation at $2000 \mathrm{rpm}$ for approximately $10 \mathrm{~min}$, the $\mathrm{CH}_{2} \mathrm{Cl}_{2}$ phase was transferred into a $7-\mathrm{ml}$ glass tube and extracted with $1 \mathrm{ml}$ sodium thiosulfate; $45 \mathrm{~min}$ of shaking was needed to hasten the extraction process. A few minutes were allowed for phase separation, then the water phase was pipetted off and injected directly into the HPLC-AFS system for separation and determination. Acid-washed glassware, analytical grade reagents, and double-distilled deionized water were used during the analysis. In order to check on the purity of the chemicals used, a number of 
chemical blanks were run; there was no evidence of any contamination in these blanks. An analytical quality control of $\mathrm{T}-\mathrm{Hg}$ and $\mathrm{MeHg}$ was achieved using certified dogfish muscle reference material (DORM-2). The values found [T-Hg: $4.56 \pm 0.46$ mg kg-1 (w/w); MeHg: $4.24 \pm 0.14 \mathrm{mg} \mathrm{kg}^{-1}$ (w/w)] agreed with the certified values [T-Hg: $4.64 \pm 0.26$ $\mathrm{mg} \mathrm{kg}^{-1}$ (w/w); MeHg: $\left.\left.4.47 \pm 0.32 \mathrm{mg} \mathrm{kg}^{-1} \mathrm{w} / \mathrm{w}\right)\right]$. For T-Se, analytical quality control was achieved using mussel standard reference material (GBW 08571). The T-Se contents found $[3.57 \pm 0.15$ $\left.\mathrm{mg} \mathrm{g}^{-1}(\mathrm{w} / \mathrm{w})\right]$ agreed with the certified values $\left[3.65 \pm 0.09 \mathrm{mg} \mathrm{g}^{-1}(\mathrm{w} / \mathrm{w})\right]$.

\section{Results and discussion}

\section{$\mathrm{T}-\mathrm{Hg}, \mathrm{MeHg}$, and $\mathrm{T}$-Se in fish}

$\mathrm{T}-\mathrm{Hg}+\mathrm{MeHg}+\mathrm{I}-\mathrm{Hg}=(\mathrm{T}-\mathrm{Hg}-\mathrm{MeHg})+\mathrm{T}-\mathrm{Se}$ concentrations in the muscle tissues of the four species listed in Table 1. The statistical analysis showed significant differences $(p<0.05)$ between the $\mathrm{T}-\mathrm{Hg}$ and $\mathrm{MeHg}$ contents among the four species with the exception of crucian carp and silver carp. The observed variability of $\mathrm{T}-\mathrm{Hg}$ and $\mathrm{MeHg}$ levels among fish of the same species was in accordance with fish size, sex, longevity, and growth rate, while among the different fish species, the $\mathrm{T}-\mathrm{Hg}$ and $\mathrm{MeHg}$ concentrations were also affected by feeding habits, trophic level, and habitat of the fish. Elevated muscle $\mathrm{Hg}$ concentration in the snakehead fish was indicative of a food-chain effect of $\mathrm{Hg}$ in the lake. The snakehead fish, a bottom dweller, is a strongly predatory fish preying on fingerling and shrimp, so it could bioaccumulate high levels of $\mathrm{T}-\mathrm{Hg}$ and $\mathrm{MeHg}$, whereas common carp and crucian carp feed on a wide variety of plankton with the result that they could assimilate much less $\mathrm{T}-\mathrm{Hg}$ and $\mathrm{MeHg}$.

There were significant correlations between $\mathrm{T}-\mathrm{Hg}$ and $\mathrm{MeHg}$ concentrations in the muscles of each fish species (Fig. 3). Of the T-Hg concentrations in the muscles, the mean $\mathrm{MeHg}$ fraction was standardly less than $50 \%$, although the fraction was highly variable. This variability and mean value are in contrast to the consistent fraction of $95 \%$ reported in the muscle of 14 species of fish using ultra-clean techniques (Bloom 1992) and the fraction of $93 \%$ reported in the muscles of four other fish species using more standard techniques (May et al. 1987). However, the values are in agreement with proportions of $\mathrm{MeHg}$ to $\mathrm{T}-\mathrm{Hg}$ (33-98\%) found by Ipolyi et al. (2004) in mussel samples.

Levels of T-Se ranged from 388.53 to $1502.25 \mu \mathrm{g} \mathrm{kg}^{-1}$ (w/w), with the greatest mean concentration found in common carp $\left[1170.59 \pm 173.56 \mu \mathrm{g} \mathrm{kg}^{-1}(\mathrm{w} / \mathrm{w})\right]$ and the lowest mean concentration found in silver carp $\left[559.49 \pm 82.68 \mu \mathrm{g} \mathrm{kg}^{-1}\right.$ (w/w)]. The muscle T-Se content was significantly different in the four fish species $(p<0.05)$, except between the snakehead fish and silver carp. It is worth noting that in the fish muscle the concentration of $\mathrm{T}-\mathrm{Hg}$ decreased exponentially with an increase of $\mathrm{T}-\mathrm{Se}$, with the negative correlation being significant in common carp (Fig. 4). The first report of the protective effect of selenite against mercury toxicity appeared in 1967 (Parizek \& Ostadalova 1967). Since then, numerous studies have shown that selenium supplementation counteracts the toxicity of exposure to mercury. The ability of selenium compounds to decrease the toxic action of mercury has been established in all species of mammals, birds, and fish investigated to date (Beijer \& Jernelov 1978;

Table 1. T-Hg, MeHg, I-Hg, T-Se concentrations $\left[\mu \mathrm{g} \mathrm{kg}{ }^{-1}(\mathrm{w} / \mathrm{w})\right] \mathrm{MeHg} / \mathrm{T}-\mathrm{Hg}$ ratios and T-Se/I-Hg molar ratios in the fish muscles.

\begin{tabular}{lccccccc}
\hline Species & $n$ & $\mathrm{~T}-\mathrm{Hg}$ & $\mathrm{MeHg}$ & $\mathrm{I}-\mathrm{Hg}$ & $\mathrm{MeHg} / \mathrm{T}-\mathrm{Hg} \mathrm{T}-\mathrm{Se}$ & $\mathrm{T}-\mathrm{Se} / \mathrm{I}-\mathrm{Hg}$ \\
\hline Silver carp & 13 & $205.48-928.32$ & $57.44-360.17$ & $37.65-622.96$ & $0.27-0.72$ & $388.58-708.74$ & $1.47-44.29$ \\
(Hypophthalmichthys molitrtix) & $428.98 \pm 241.14$ & $195.15 \pm 100.50$ & $233.83 \pm 164.64$ & $0.48 \pm 0.16$ & $559.49 \pm 82.68$ & $10.45 \pm 11.25$ \\
Common carp & 10 & $23.57-210.43$ & $5.44-126.06$ & $5.87-84.37$ & $0.18-0.85$ & $897.92-1502.25$ & $25.04-507.88$ \\
(Cyprinus carpio) & & $78.88 \pm 63.67$ & $39.29 \pm 39.21$ & $39.59 \pm 27.44$ & $0.44 \pm 0.21$ & $1170.59 \pm 173.56$ & $132.25 \pm 141.96$ \\
Crucian carp & 11 & $130.74-1360.40$ & $52.33-643.80$ & $78.41-716.60$ & $0.29-0.55$ & $614.58-868.41$ & $2.02-25.46$ \\
(Carassius carassius) & & $422.95 \pm 383.98$ & $184.84 \pm 182.47$ & $238.11 \pm 204.48$ & $0.43 \pm 0.08$ & $759.01 \pm 85.17$ & $12.12 \pm 7.28$ \\
Snakehead fish & 6 & $428.81-1199.39$ & $164.38-498.86$ & $243.65-700.53$ & $0.38-0.54$ & $505.00-642.36$ & $1.86-5.49$ \\
(Ophiocephalus argus cantor) & $827.11 \pm 333.96$ & $371.12 \pm 134.19$ & $455.98 \pm 206.23$ & $0.46 \pm 0.06$ & $565.94 \pm 52.52$ & $3.59 \pm 1.79$ \\
\hline
\end{tabular}



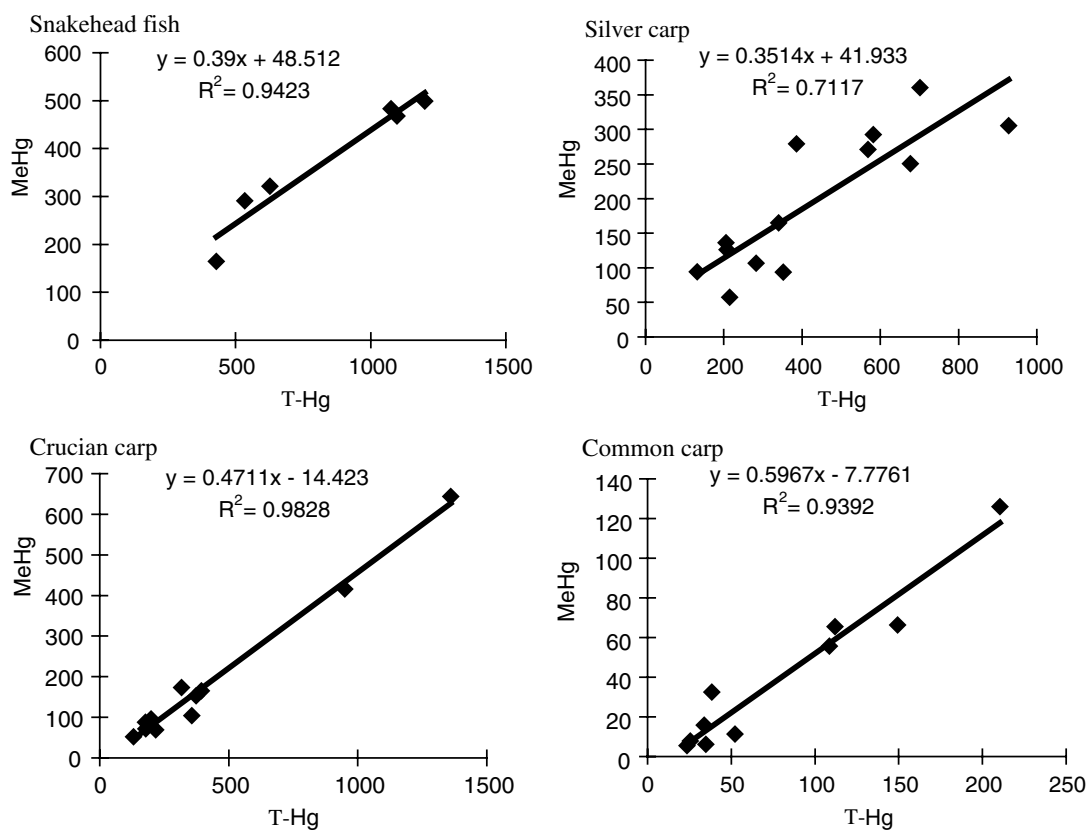

Fig. 3. $\mathrm{T}-\mathrm{Hg}$ and $\mathrm{MeHg}$ concentrations $\left[\mu \mathrm{g} \mathrm{kg}^{-1}(\mathrm{w} / \mathrm{w})\right]$ in the muscle samples of the four fish species.

Culvin-Aralar \& Furness 1991). However, field studies on the $\mathrm{Se}-\mathrm{Hg}$ interaction in freshwater fish are relatively scarce, and the data collected from these are often controversial (Chen et al. 2001). Various studies have shown that there is either no correlation (Cappon \& Smith 1981) or a negative one (Paulsson \& Lundbergh 1991; Chen et al. 2001) between the concentrations of selenium and mercury in fish. Sheline \& Schmidt-Nielsen (1977) investigated the $\mathrm{Hg}-\mathrm{Se}$ interaction in the fish Fundulus heteroclitus and found little effect of selenium on the overall body retention of mercury.
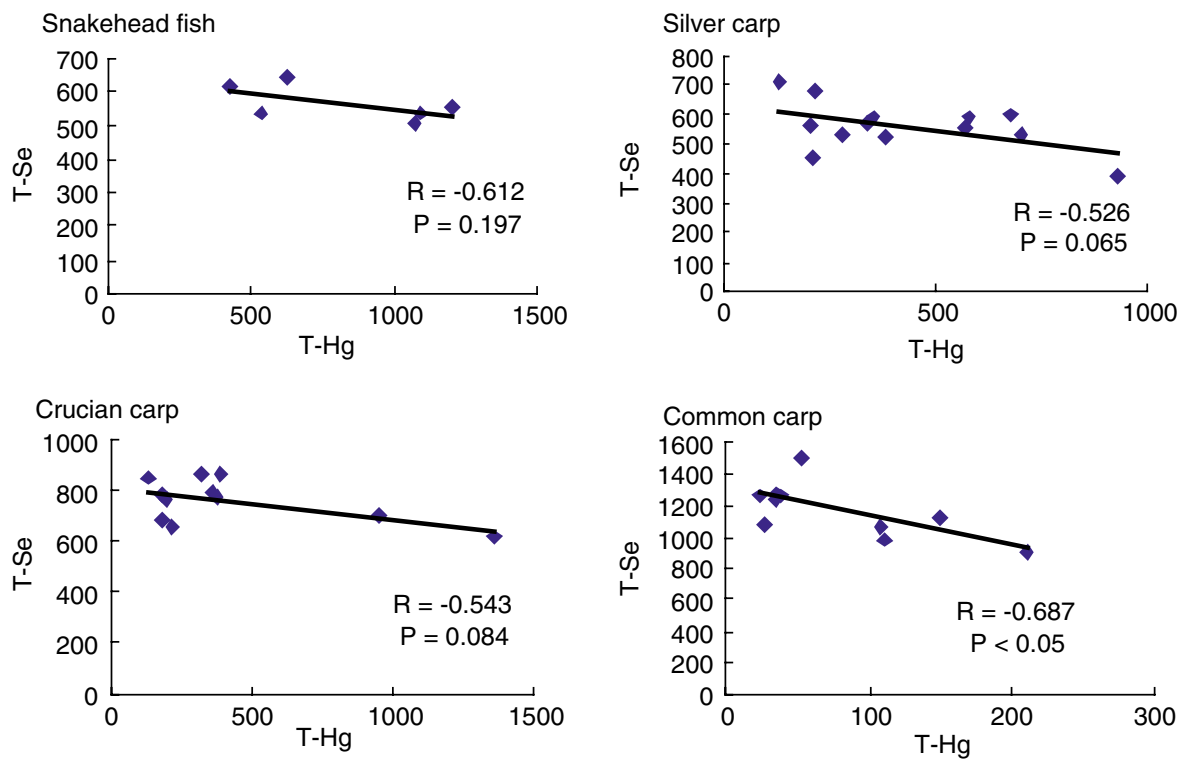

Fig. 4. T-Hg and T-Se concentrations $\left[\mu \mathrm{g} \mathrm{kg}^{-1}(\mathrm{w} / \mathrm{w})\right]$ in the muscle samples of four fish species. 
Table 2. PTWI regulated by FAO/WHO and estimated Chinese weekly intake of $\mathrm{T}-\mathrm{Hg}$ and $\mathrm{MeHg}(\mu \mathrm{g})$.

\begin{tabular}{lclcc}
\hline Species & $\begin{array}{l}\text { T-Hg estimated } \\
\text { weekly intake }\end{array}$ & $\begin{array}{l}\text { FAO/WHO } \\
\text { PTWI of T-Hg }\end{array}$ & $\begin{array}{l}\text { MeHg estimated } \\
\text { weekly intake }\end{array}$ & $\begin{array}{l}\text { FAO/WHO } \\
\text { PTWI of MeHg }\end{array}$ \\
\hline Silver carp & 600.57 & $<300$ & 273.21 & $<100$ \\
Common carp & 110.43 & & 55.01 & \\
Crucian carp & 592.13 & & 258.78 & \\
Snakehead fish & 1157.95 & & 519.57 & \\
\hline
\end{tabular}

Other studies, however, have shown that the addition of selenium is an effective way to reduce mercury concentrations in pike (Esox lucius) and perch (Perca flavescens) when the appropriate doses and addition periods were used (Turner \& Swick 1983). Southworth et al. (2000) observed a long-term increase in mercury concentrations in the largemouth bass following the reduction of waterborne selenium. Chen et al. (2001) further found a significantly negative correlation between the mercury concentrations in perch and walleye muscles and selenium concentrations. The mechanism of interaction between these two elements in the bioassimilation processes has not yet been clarified although it appears to be related to the element competition between mercury and selenium in fish muscles. One hypothesis is as follows: when an organism is exposed to high concentrations of mercury, selenium could be released from selenium-binding protein of muscle to liver, the primary detoxification organ, to antagonize the toxicity of mercury, thus causing a decrease in muscle selenium levels. However, the interaction of mercury and selenium can be either antagonistic or synergistic, primarily depending on exposure concentrations and the form of mercury involved. The geochemistry of Ya-Er Lake should also be taken into account when speculating on the bioassimilation of mercury and selenium.

\section{An assessment of mercury exposure in man}

Freshwater fish is one of the more important protein sources for humans, and China is not an exception. In general, food intake provides the major exposure route of organisms to mercury (D'tri 1990), and the food exposure route provides $90 \%$ of the $\mathrm{MeHg}$ bioaccumulated in the fish body (Hall et al. 1997). In this study, attention must be given to the fact that of all the muscles sampled $38.46 \%$ of those of the silver carp, $18.18 \%$ of those of the crucian carp, and $100 \%$ of those of the snakehead fish contained $\mathrm{T}-\mathrm{Hg}$ levels exceeding the maximum allowable limit recommended by WHO for most fish species $\left[0.4 \mathrm{mg} \mathrm{kg}^{-1}\right.$ (w/w); WHO 1989], while none of the muscle samples from the common carp contained $\mathrm{T}-\mathrm{Hg}$ levels exceeding the maximum allowable concentration.

The Joint Food and Agriculture Organization/ World Health Organization (FAO/WHO) Expert Committee on Food Additives has established regulatory guidelines regarding dietary mercury intake. It recommends a provisional tolerable weekly intake (PTWI) of $300 \mu \mathrm{g}$ of $\mathrm{T}-\mathrm{Hg}$ per person, of which no more than $100 \mu \mathrm{g}$ should be present as MeHg (WHO 2003). In the Ya-Er Lake area, fish is the primary protein intake source in the diet of residents, and the average consumption of fresh fish is about $200 \mathrm{~g} \mathrm{day}^{-1}$. The weekly intake of $\mathrm{T}-\mathrm{Hg}$ and $\mathrm{MeHg}$ are consequently between 110.43 and $1157.95 \mu \mathrm{g}$ and between 55.01 and $519.57 \mu \mathrm{g}$, respectively (Table 2). As can be seen from the table, the estimated weekly intake of $\mathrm{T}-\mathrm{Hg}$ and $\mathrm{MeHg}$ from three fish species exceeds the established PTWI except for common carp. The presence of such high levels of toxic $\mathrm{MeHg}$ in fish muscle, in combination with the fact that the consumption of contaminated fish is the main source of mercury intake in people not occupationally exposed (Galal-Gorchev 1993; Cuadrado et al. 1995), amply underlines the need for preventive measures to safeguard public health.

\section{Acknowledgements}

Financial support was provided by the National Basic Research Program of China (grant no. 2003CB415005) and the Chinese Academy of Sciences (grant nos. K3CX2-SW-128, K2CX3SW-431). The authors are grateful to Mr. Jianbo Shi for his technical assistance. 


\section{References}

Bakir F, Damluji SF, Amin-Zaki L et al., 1973 Methylmercury poisoning in Iraq. Science 181, 230-241.

Barghigiani G, Pellegrini D, D’Ulivo A, De Ranieri S. 1991 Mercury assessment and its relation to selenium levels in edible species of the Northern Tyrrhenian Sea. Mar Pollut Bull 22, 406-409.

Beijer K, Jernelov A. 1978 Ecological aspects of mercuryselenium interaction in the marine environment. Environ Health Perspect 25, 43-45.

Bloom NS. 1992 On the chemical form of mercury in edible fish and marine invertebrate tissues. Can J Fish Aquat Sci 49, 1010-1017.

Cappon CJ, Smith JC. 1981 Mercury and selenium content and chemical form in fish muscle. Arch Contam Toxicol 10, 305319.

Chen YW, Belzile N, Guun JM. 2001 Antagonistic effect of selenium on mercury assimilation by fish populations near Sudbury metal smelters? Limnol Oceanogr 46, 1814-1818.

Cuadrado C, Kumpulainen J, Moreiras O. 1995 Lead, and cadmium and mercury contents in average Spanish market basket diets from Galicia, Valencia, Andalucia and Madrid. Food Addit Contam 12, 107-118.

Culvin-Aralar LA, Furness RW. 1991 Mercury and selenium interaction: a review. Ecotoxicol Environ Safety 21, 348-364.

D'tri FM. 1990 The biomethylation and cycling of selected metals and metalloids in aquatic sediment. In Baudo R Giesy J, Muntau H, eds. Sediments: Chemistry and Toxicity of Inpace Pollutants. Ann Arbor: Lewis Publ, pp. 163-214.

Eyssen GEM, Ruedy J. 1983 Methylmercury exposure in Northern Québec: I. Neurologic findings in adults. $A m J$ Epidemiol 118, 461-469.

FAO (1983) Fish feeds and feeding in developing countries - an interim report on the ADCP Feed Development Programme. ADCP/REP/83/18.97 FAO, Rome.

Galal-Gorchev H. 1993 Dietary intake, levels in food and estimated intake of lead, cadmium and mercury. Food Addit Contam 10, 115-128.

Hall BD, Bodaly RA, Fudge RJP, Rudd JWM, Rosenberg DM. 1997 Food as the dominant pathway of methylmercury uptake by fish. Water Air Soil Pollut 100, 13-24.

Ipolyi I, Massanisso P, Sposato S, Fodor P, Morabito R. 2004 Concentration levels of total and methylmercury in mussel samples collected along the coasts of Sardinia Island (Italy). Anal Chim Acta 505(1), 145-151.

Liang LN, Jiang GB, Liu JF, Hu JT. 2003 Speciation analysis of mercury in seafood by using high-performance liquid chromatography on-line coupled with cold-vapor atomic fluorescence spectrometry via a post column microwave digestion. Anal Chim Acta 477, 131-137.

Lyle JM. 1986 Mercury and selenium concentrations in sharks from Northern Australian waters. Aust J Mar Fresh Res 37, 309-321.
May K, Stoeppler M, Reisinger K. 1987 Studies of the ratio of total mercury/methylmercury in the aquatic food chain. Toxicol Environ Chem 13, 153-159.

Michael G. 2003 Cases of mercury exposure, bioavailability, and absorption. Ecotoxicol Environ Safe 56, 174-179.

Monteiro LR, Lopes HD. 1990 Mercury content of swordfish, Xiphias glaudius, in relation to length, weight, age, and sex. Mar Pollut Bull 21, 293-296.

Nakagawa R, Yumita Y, Hiromoto M. 1997 Total mercury intake from fish and shellfish by Japanese people. Chemosphere 35, 2909-2913.

Nriagu JO, Pfeiffer WC, Malm O, de Souza CMM, Mierle G. 1992 Mercury pollution in Brazil. Nature 356, 389.

Parizek J, Ostadalova I. 1967 The protective effect of small amounts of selenite in sublimate intoxication. Experiential 23, 142-143.

Paulsson L, Lundbergh K. 1991 Treatment of mercury contaminated fish by selenium addition. Water Air Soil Pollut 56, 833-841.

Sheline J, Schmidt-Nielsen B. 1977 Methylmercury-Selenium: Interaction in the Killifish Fundulus heteroclitus. In Vernberg FJ, Calabrese A, Thurberg FP, Vernberg WB, eds. Physiological Responses of Marine Biota to Pollutants. New York: Academic Press, pp. 188-193.

Southworth GR, Peterson MJ, Ryon MG. 2000 Long-term increased bioaccumulation of mercury in largemouth bass follows reduction of waterborne selenium. Chemosphere 41, 1101-1105.

Storelli MM, Marcotrigiano GO. 2001 Total mercury levels in muscle tissue of swordfish (Xiphias glaudius) and bluefin tuna (Thunnus thynnus) from the Mediterranean sea. J Food Prot 64, 1058-1061.

Storelli MM, Giacominelli SR, Marcotrigiano GO. 2002 Total and methylmercury residues in tuna-fish from Mediterranean sea. Food Addit Contam 19, 715-720.

Tsubaki T, Irukayama K (eds) (1977) Minamata disease: methylmercury poisoning in Minamata and Niigata, Japan. Elsevier, New York.

Turner MA, Swick AL. 1983 The English-Wabigoon river system: 4 interaction between mercury and selenium accumulated from waterborne and dietary sources by northern pike (Esox lucius). Can J Fish Aquat Sci 40, 2241-2250.

WHO 1989 Evaluation of Certain Food Additives and Contaminants. WHO Technical Report Series 776, Geneva: World Health Organization.

WHO (2003) Summary and conclusions of the 61st Meeting of the Joint FAO/WHO Expert Committee on Food Additives (JECFA). JECFA/61/SC, Rome.

US Environmental Protection Agency (EPA) (2001) Water Quality Criterion for the Protection of Human Health: Methylmercury. EPA-823-R-01-001. 